\title{
Financial and Strategic Factors Associated with the Profitability and Growth of SME in Portugal
}

\author{
Ana Paula Silva \\ Faculty of Economics \& Management, Lusófona University \\ Rua Augusto Rosa, 24, 4000-0980 Porto, Portugal \\ Tel: 351-22-207-3230Ｅ-mail: ana.silva@ulp.pt \\ C. Machado Santos (Corresponding author) \\ Department of Economics, Sociology \& Management, UTAD University \\ Apartado 1013, 5001-801 Vila Real, Portugal \\ Tel: 351-25-935-0000_E-mail: cmsantos@utad.pt
}

Received: December 8, 2011

Accepted: December 29, 2011

Published: March 1, 2012

doi:10.5539/ijef.v4n3p46

URL: http://dx.doi.org/10.5539/ijef.v4n3p46

We thank the participants of the 2011 Market \& Organizations Research Seminars, as well as other anonymous contributions, for early versions of this paper. Obviously, remaining errors are responsibility of the authors.

\begin{abstract}
Drawing on literature from finance and strategic management, eight likely factors associated with the profitability and growth of unquoted, small and medium-sized enterprises (SMEs) are identified and evaluated. These factors are: leverage, liquidity, education, industry performance, low cost, differentiation, product focus and customer focus. The sample comprises 134 unquoted SMEs aged five years or more, operating in different sectors throughout the main districts of Portugal. Data are collected through face-to-face interviews and these are supplemented with secondary sources. Twenty-one independent variables are identified and LISREL is used to produce measurement equations relating the variables to factors. Hypotheses concerning the factors' impact on profit and growth are tested through structural equation modelling using LISREL. The results show that low debt, effective liquidity management, operation in a profitable sector, differentiation, the avoidance of low cost and customer focus favour SMEs' profitability. For high growth, although effective liquidity management and differentiation remain as key factors, they are joined by a product focus. These results carry a number of important implications for SME strategy most notably that there may not be one set of strategies that maximise both profitability and growth.
\end{abstract}

Keywords: Profitability, Growth, SMEs, Performance

\section{Introduction}

After lagging behind Europe for nearly one century, particularly in the 1920s, Portugal started a slow process of convergence to the average levels of the EU, especially between the 1950s and the 1990s, abandoning the qualification of undeveloped country in light of the international organisations' criteria. Major changes have taken place since the freedom-based regime set up with the 25 April 1974 Revolution. The Portuguese economy has become more open, especially after accession to the EU. Despite the success of its past economic growth, the convergence process of Portugal is far from complete. To reduce the gap and to give rise to the challenges posed by globalisation and the Euro, efforts are being directed to promote the growth, productivity, and competitiveness of national firms.

That many countries have directed increasing attention to the development of their domestic SMEs to propel economic growth is a phenomenon especially evident in the developing and newly industrialised economies, which traditionally have been mostly powered by foreign investments. The purpose of this paper is to contribute to the understanding of the Portuguese SME sector by reporting on a study of the factors associated with their growth and profitability focussing on financial and strategic factors, and is structured as follows: the next section presents a literature review on the main issues analyzed, such as, capital structure/leverage; liquidity; education; industry performance; low cost strategy; differentiation; product focus; customer focus. Section three describes the variables, 
hypotheses and sample. Section four explains the structural equation modeling. Section five reports the results of the empirical analysis and Section six concludes.

\section{Literature Review}

\subsection{Capital Structure/Leverage}

One of the most debatable issues in the theory of finance has been the theory of capital structure (leverage) since the celebrated work of Modigliani \& Miller $(1958,1963)$. Thereafter, a number of theories have been put forth by bringing forward a number of frictions omitted in the original work of Modigliani \& Miller so as to explain firms' optimal capital structure, should this exist, as a function of the various costs and benefits from debt and equity financing. Most celebrated are the Static Trade-off Theory; Agency Theory (Jensen \& Meckling, 1976; Myers, 1977); Signalling Theory (Ross, 1977); the Pecking Order Theory (pioneered by Myers (1984), drawing largely on Myers \& Majluf (1984)); and the Credit Rationing Theory (Stiglitz \& Weiss, 1981).

However, research in the area is mostly confined to the determinants of capital structure, among which there are often performance measures (e.g. Booth, Aivazian et al. (2001); Chittenden et al. (1996); Hall et al. (2000); Jordan et al. (1998); Michaelas et al. (1999); Titman \& Wessels (1988); Toy et al. (1974); Mira (2003); Solano \& Teruel (2006); Caballero et al. (2010)). The Pecking Order Theory holds up well for SMEs suggesting that there is a negative relationship between leverage and debt with the more profitable firms needing to borrow less. The results for growth have been mixed but generally show a positive if not always significant relationship.

\subsection{Liquidity}

Liquidity, understood in terms of the availability of cash or near cash resources to meet short-term obligations, is a theme associated with the problems posed by asymmetry of information, agency relationships and credit rationing, all hinting at liquidity being a major problem for the smaller firms. This issue is an extension of the capital structure one. That smaller firms live under tight liquidity constraints is basically a matter of consensus (e.g. Chittenden et al. (1996); Chow \& Fung (2000); Gopinath (1995); Berger \& Udell (2005); Klapper et al. (2006); Teruel \& Solano $(2008,2010)$ ). Mechanisms through which banks restrain firms from engaging in risk-shifting behaviour (besides strict covenants and collateral) include short maturities, especially for the very small firms that do not have audited financial statements and to whom effective covenants, typically attached to medium and long-term debt, cannot therefore be imposed (Berger \& Udell, 1998). Financial restrictions are largely centred on long-term loans because while debt contracts with long maturity provide the borrower with greater opportunity to shift to riskier investments and suffer financial distress, on the other hand, through a sequence of short-term credits the lender can force renegotiation frequently. For example, while collateral for long-term debt is fixed assets, collateral for short-term loans is typically accounts receivable or, as a second choice, inventory/work-in-progress (Duryee, 1994). For all of these, small firms are induced to resemble long-term finance with continuing renewal of short-term finance, not only from banks (including credit cards and overdrafts) but also from suppliers, which have relatively high cost, increase financial risk (Kotey, 1999), and damage liquidity (Chittenden et al., 1996). However, under the stress of credit-rationing and limited access to outside capital markets, unlisted SMEs might not find a better option than to take advantage of whatever short-term credit is available irrespective of cost. Good liquidity management should reduce impediments to growth and lead to higher profitability.

\subsection{Education}

Due to the emerging prominence of the Resource-Based View of competitive advantage, in the 1990s strategic management research underwent a major shift in focus from the role of industry structure and strategic positioning of firms to their bundle of resources and capabilities (Hawawini et al., 2003; Hoskisson et al., 1999; Spanos et al., 2004), thereby the firm being re-established as the critical unit of analysis (Hoopes et al., 2003; Lockett \& Thompson, 2001; Spanos \& Lioukas, 2001).

When Penrose (1959) argues that the firm-specific tacit knowledge of managers is the major inducement and deterrent of their firms' growth rate, she implies the more tacit knowledge a manager holds the better he/she will interpret environmental stimuli to perceive and pursue emerging opportunities for growth, and consequently, he/she will improve the odds of making the right decisions under limited information conditions, i.e., profit-maximising decisions. Penrose (1959) maintains that managers with higher entrepreneurial ability (which Johnson et al., 1999, argue may be enhanced by education) should perceive and pursue more and better growth opportunities in the environment as well as recombine resources efficiently and effectively, thereby sustaining superior returns. A positive relationship is thus expected between the education level and both growth and profitability.

\subsection{Industry Performance}

From the 1960s through the late 1980s the Market-Based View dominated analysis of variance in performance (Hawawini et al., 2003; Hoskisson et al., 1999; Lockett \& Thompson, 2001; McGahan \& Porter, 2002). It draws 
from Industrial Organisation economics, whose basic model follows from the Structure (environment) - Conduct (strategy)- Performance paradigm which culminated in Porter's (1980) now classical formulation of the competitive strategy framework (Lockett \& Thompson, 2001; Makhija, 2003; Rugman \& Verbeke, 2002; Spanos \& Lioukas, 2001; Spanos et al., 2004; Foreman-Peck et al., 2006).

Through his "Five Forces Model", Porter (1980) predicts industry profitability, which is assumed to be a major determinant of firms' profitability. Consistently, most research evaluating industry effects on profitability incorporates several industry variables among the predictors' set (e.g. Pelham, 2000; Spanos \& Lioukas, 2001; Van Caneghem et al. 2009, Daskalakis et al. (2009)).

Industry profitability itself can be taken as a surrogate for the industry structural forces and for the industry efficient scale. Furthermore, the sector/markets in which the firm operates is one of the six elements comprised by the component "The Firm", which is the second of three components identified by Storey (1994) to make up the key determinants that when appropriately combined would allow the small firms to achieve fast growth. Based on a survey of 14 empirical studies of small firm growth, the author (1994) concludes the bulk of studies indicate significant differences between sectors in terms of the typical growth rates of firms. It could, therefore, be expected that there is a positive relationship between the profitability of the firm and its industry and also between the growth of the firm and its industry.

\subsection{Low Cost Strategy}

Porter's $(1980,1985)$ theory of generic competitive strategy can be applied to SMEs. Porter's theory is composed of two major elements. In this study, Porter describes competitive strategies in terms of their market scope (focused versus broad) and contends there are two sources of competitive advantage: overall cost leadership and differentiation. It is questionable whether a low cost strategy can be successfully achieved by SMEs. Low cost hinges essentially on the economies of scale and experience arising from large volumes of sales, which are unlikely events for SMEs operating under conditions of monopolistic competition and whose shallow pockets are not able to keep up with a swift expansion of production capacity or other means to achieve large volume. Thus, regardless of how much SMEs may economise they are likely to remain too cost disadvantaged to become cost leaders and respond in kind to pressures on price from their large counterparts. Lending support of this view, Clark et al. (2001) based on in-depth interviews with 44 SMEs' owner-managers, identified price competition as a major constraint to growth since it imposes low costs. It is unlikely, therefore, that there would be a positive relationship between a low cost approach and growth and profitability.

\subsection{Differentiation}

Although differentiation may require a firm's engagement in some costly activities, it is possible that the SME can position itself as a differentiator without facing unaffordable expenditures. A distinctive service is a competitive differentiation strategy strongly supported by extant research and on which SMEs may concentrate to position themselves as differentiators. Dess \& Davis (1984) report the case of one CEO belonging to the differentiation cluster arguing his firm's enjoyable high profit margins emerging from premium prices hinged more upon the firm's differentiation than upon the product differentiation, namely upon a reputation for superior service and quick response to buyer needs.

Horn \& Harvey (1998) underline the importance of fast response for firms to survive and grow in a century where the key words are competition, dynamism, and globalisation. Sulek et al. (1995) note service is an important differentiating factor among otherwise similar competitors, and they further argue one way to improve service quality consists of fine tuning the service delivery system. David et al. (2002) argue a differentiation strategy is supported by, among other things, a high level of service, responsiveness to customer requests, and manufacturing flexibility. SMEs, being in principle less bureaucratic, with a simpler structure, greater flexibility and closer contact between senior managers and customers than their larger counterparts, should be in a better position to develop personal relationships with customers and to serve them on time, thereby providing better service to meet particular needs and avoiding delivery delays that upset customers so much. An order that is due at the client today may be useless tomorrow and even imply costs to the firm. A differentiation strategy should lead to higher growth and profitability.

\subsection{Product Focus}

Porter (1980) argues unless a focus strategy is used to target a neglected market, it usually involves a trade-off between profitability and sales volume, i.e., focus may limit expansion opportunities thereby constraining the overall market share achievable. Dess \& Davis (1984) challenge this commonly acknowledged trade-off. Furthermore, Porter was focused on giant firms organised on a multinational basis whereas for the average SME the overall 
market share achievable is small anyway. Thus, we postulate focus should also promote growth not only because it economises and optimises resources usage but also because of the opportunity focusers may have to serve the targeted segments better than broadly-targeted competitors since these latter serve others at the same time. Furthermore, despite the major argument in the literature that product diversity allows economies of scope across different product lines, oftentimes there is a trade-off between cost reduction from a configuration exploiting commonality across product lines (technological and/or market characteristics) and the differentiation premium because commonality dilutes differentiation across products; thus, the firm may have to forego a premium price for the better products causing overall profits to decline (Desai et al., 2001). Clearly, this applies where firms pursue a differentiation strategy to command premium prices and higher margins, which is likely to be adequate and necessary for SMEs. A product focus should lead to higher growth and profitability.

\subsection{Customer Focus}

Customer concentration is one of the elements of the component "Strategy", the third of three components identified by Storey (1994) to make up the key determinants that when appropriately combined would allow the small firms to achieve fast growth. Although it is widely acknowledged that reliance on a small number of customers confers them great bargaining power and represents additional risk, on the other hand, the holding of a narrow customer base allows reducing the costs of marketing and the general overheads, and it promotes customer loyalty through a closer customer-relationship. Thus, as reasoned in Birley \& Westhead (1990), customer focus should be one of the most important sources of competitive advantage and thus, of above average performance for SMEs both in terms of growth and profitability.

\section{Variables, Hypothesis and Sample}

The variables were ratios, dummies or absolute values, averaged for the years 2007 to 2009 as appropriate. The two dependent variables were:

ROA: The SME's return on investment $=$ net profit before interest and tax $/$ total assets and

GROWTH: The SME's turnover growth $=($ Turnover $2009-$ Turnover 2007)/Turnover 2007

Twenty-one independent variables were classified and measured as described below with the relevant hypotheses $(\mathrm{H}$ $1-8)$.

\section{H1: Leverage}

There is a negative relationship between the degree of leverage and SMEs' profitability and a positive one with their growth.

AVDER1: debt to equity ratio $=$ Total Debt/Total Equity

AVAF: financial autonomy ratio $=$ Total Equity/Total Assets

\section{H2: Liquidity}

There is a positive relationship between effective liquidity management and SMEs' profitability and growth.

AVASTURN: assets turnover ratio $=$ Net Sales/Total Assets

AVWORKCA: net working capital ratio $=($ Current Assets-Current Liabilities $) /$ Total assets

LIQCRISI: whether the firm has experienced a severe liquidity crisis over the past 5 years, $1=$ Yes, $0=$ No

SUPHONE: whether the firm frequently pays suppliers late, $1=$ Frequently, $0=$ Not Frequently

SUPDISC: whether the firm frequently uses early payment discounts, $1=$ Frequently, $0=$ Not Frequently

\section{H3: Education}

There is a positive relationship between the years of formal education of the most influential manager in the SME and its profitability and growth.

EDU1: number of years of education of the most influential manager in the firm.

\section{H4: Industry performance}

There is a positive relationship between the profitability or growth of the industry in which an SME operates and its own profitability or growth. For profitability,

CROA: sector ROA = Sector EBIT/Total Assets, averages for 2007, 2008 and 2009

Alternatively, for growth,

CTURNGRW: sector turnover growth $=($ Sector Turnover $2009-2007) /$ Sector Turnover 2007. 


\section{H5: Low cost}

There is no relationship or a negative relationship between a low cost approach and SMEs' profitability and growth.

BUDGET: whether the firm prepares budgets at least on a yearly basis, $1=\mathrm{Yes}, 0=\mathrm{No}$

LOWCOST: importance attached to continuing, overriding concern for the lowest cost per unit $=$ percentage importance attached

OWNSTOR: whether the firm has its own stores, $1=$ Yes, $0=$ No

MPLIST: whether the firm is able to extract a reliable and computerised list of stocks of raw materials at any time, $1=$ Yes, $0=$ No

TRUEACC: whether the firm has a true cost accounting system in place, $1=\mathrm{Yes}, 0=$ No.

\section{H6: Differentiation}

There is a positive relationship between differentiation and SMEs' profitability and growth.

OWNPROD: percentage of turnover that is own-product.

BRANPRIC: whether brand name, product prestige, or firm reputation is important for the firm's pricing,

$1=$ Yes to any, otherwise $=0$

PRODCERT: whether major product has a quality stamp on it, $1=\mathrm{Yes}, 0=\mathrm{No}$

PRODELAY: whether deliveries delays occur at least twice a year, $1=\mathrm{Yes}, 0=\mathrm{No}$

\section{H7: Product focus}

There is a positive relationship between a product focus and SMEs' profitability and growth.

PRODFOCU: percentage of total turnover contributed by the major product

\section{H8: Customer focus}

There is a positive relationship between a customer focus and SMEs' profitability and growth.

CUSFOCUS: percentage of total turnover contributed by the most important customer type.

The sample comprises 134 unquoted SMEs aged five years or more, operating in different sectors throughout the main districts of Portugal. Data were mostly collected through face-to-face interviews and were supplemented with secondary data.

\section{Structural Equations Modelling and Lisrel}

Structural Equation Modelling (SEM) is a collection of statistical techniques to define, fit and test structural relationships between a number of predictors and one or more dependent variables (Jöreskog \& Sörbom, 1993; Ullman, 2001). The term 'structural' is employed because relationships in SEM account for variation among variables that are subject to measurement error or uncontrolled variation, which is the case for every research field where controlled experimentation is not feasible and the scope of the problem goes beyond simple empirical prediction. A structural equation model is a set of sub-models each one represented by a mathematical equation with the dependent variable as a function of the direct 'causes'; thus, it is a system of linear equations that represent the hypothesised cause and effect structural relationships among quantitative variables (Jöreskog \& Sörbom, 1993; Tacq, 1997). The problem in SEM is that of estimating the coefficients of such linear structural equations (Jöreskog \& Sörbom, 1993).

Historically SEM has been referred to as 'causal modelling'. However, just like in regression, causality in SEM remains a design issue: there is nothing causal about SEM in the statistical sense as many wrongly believe (Shook et al., 2004; Ullman, 2001). In every uncontrolled observational study the change in the dependent variable that accompanies a unit change in any one predictor does include not only the effect of that predictor but also the effect of any confounding variables that might be changing simultaneously (Field, 2000; Wonnacott \& Wonnacott, 1990), from what follows causality can only be established out of experimental settings (Tabachnik \& Fidell, 2001), out of strong theoretical underpinnings for cross-sectional research (Shook et al., 2004), or in longitudinal research, where the temporal ordering of variables is demonstrated (Kelloway, 1995).

Although the concept of SEM was firstly introduced by Sewell Wright (a population biologist at the University of Chicago) more than 80 years ago, it was only over the past 30 years that it became a prominent form of data analysis, thanks to the LISREL programme which has meanwhile become synonymous with SEM (Jöreskog \& Sörbom, 1993; Toit \& Toit, 2001). The LISREL methodology development started in 1970 with Prof. Karl Jöreskog and five years later the first LISREL programme (version 3) was being published (Toit \& Toit, 2001). LISREL stands for 'Linear 
Structural Relations', though its current version is also capable of handling non-linear relationships (Toit \& Toit, 2001).

\section{Results}

\subsection{Measurement Equations}

LISREL was used to reduce the above 21 variables to nine which were named: nodebt, lackliq, educatio, roapot, growpot, lowcost, different, prodfocu and cusfocus. The measurement equations are presented in Table 1 (see appendix 1 for parameter details).

\section{Insert Table 1 Here}

The equations reported in Table 1 resulted in four that combined variables and five that comprised the original single variable and can be summarized as follows in Table 2:

Insert Table 2 Here

\subsection{Structural Equations}

The nine variables were then subject to structural equation modelling in LISREL. Seven of the variables were common to the two dependent variables and two were used alternatively for ROA (roapot) and growth (growpot). The results are shown in Table 3 .

Insert Table 3 Here

Since high levels of correlation were found between some factors, orthogonal rotations were performed to deal with this. For example, for "nodebt" and "lackliq" the correlation was $-0.682, \mathrm{p}<0.001$, so the syntax line "Set covariance of "nodebt" and "lackliq" to 0" was added and the analysis rerun to check for any effects on sign and significance. This resulted in a change in sign and, or, significance for some factors in relation to profitability and, or, growth. The results for the t-tests after rotation are shown in Table 4 below.

Insert Table 4 Here

The results shown in Exhibit 4 confirm many of the hypothesised relationships. For "nodebt" and ROA, because it was hypothesised that there would be a negative relationship between debt and profitability, a positive relationship would be expected for "nodebt". This is the case and is significant confirming the hypothesis. For growth, it was hypothesised that there would be a positive relationship with debt and so a negative one with "nodebt". This is the case but it is not significant.

The results for "lackliq" are in the hypothesised direction for both profitability and growth. As with "nodebt" the expected sign is the reverse of that hypothesised which was positive for liquidity so negative for a lack of liquidity. Both results are significant suggesting that this is a key factor for both profitability and growth.

Years of education are positively associated with profitability and growth, as hypothesised but are not significant. This does not disprove the popular notion that good management is learnt from experience not formal education.

The profitability of the sector in which an SME operates has a significant positive effect on its own profitability as hypothesised but there is no significant effect of sector growth on the individual SME's growth.

As hypothesised, there is a negative link between "lowcost" and profitability and growth but this is only significant for profitability.

Lastly, differentiation is, as expected, positively and significantly related to profitability and growth.

Interestingly, although both product focus and customer focus were expected to positively affect profitability and growth, the results show that they are both positively related to growth (significantly for prodfocu) and both negatively related to profitability (significantly for cusfocus).

\section{Conclusions}

The results show that low debt, effective liquidity management, operation in a profitable sector, the avoidance of a low cost approach, the use of differentiation and the avoidance of a customer focus are associated with SMEs' profitability. For high growth, effective liquidity management and differentiation remain important but a product focus is also required. These results carry a number of important implications for SME strategy.

Of immediate concern is the finding that there may not be one set of strategies that maximise both profitability and growth. Indeed of the nine factors only two, effective liquidity management and differentiation, seem to pay off for both. From then on a trade-off may be required or a decision to pursue one or the other of profitability or growth. 
Secondly, the result for the relationship between leverage and profitability is less useful than might appear as far as strategic implications are concerned. As was confirmed, there is a significant negative relationship between leverage and profitability for SMEs and this is explained by the Pecking Order Theory (POT). In turn, the POT reflects agency-type problems and information asymmetry in lending to, and borrowing by, SMEs rather than strategic choices by SMEs. Highly profitable SMEs need to borrow less than less profitable ones. Not borrowing to achieve profit confuses the direction of causation and is not a feasible strategy.

Thirdly, the results show the importance of liquidity management and differentiation. Whilst liquidity management may be a relatively unglamorous aspect of management, its inclusion as a strategy is likely to reap rewards both in terms of profitability and growth as is a strategy of differentiation.

Finally, the results show that SMEs could adopt different strategies depending on whether their aim is high profitability or high growth. It is conceivable that, whilst profitability should be the key concern, SMEs may want to grow rapidly at certain times in order to, for example, penetrate a market, increase market share or achieve a stock market flotation. Consequently, profitable periods may be preceded and, or, followed by growth maximising periods. In either case, strategy should emphasise liquidity management and differentiation but a growth strategy should emphasise a product focus and a profitability strategy should emphasise seeking out a profitable sector and avoidance of a customer focus.

\section{References}

Berger, A. N., \& Udell, G. F. (1998). The Economics of Small Business Finance: the Roles of Private Equity and Debt Markets in the Financial Growth Cycle. Journal of Banking and Finance, 22(6), 613-673. http://dx.doi.org/10.1016/S0378-4266(98)00038-7

Berger, A. N., \& Udell, G. F. (2005). A More Complete Conceptual Framework for Financing of Small and Medium Enterprises (December). World Bank Policy Research Working Paper No. 3795.

Birley, S., \& Westhead, P. (1990). Growth and Performance Contrasts Between Types of Small Firms. Strategic Management Journal, 11, 535-557. http://dx.doi.org/10.1177/0266242600191001

Booth, L., Aivazian, V., Demirguc-Kunt, A., \& Maksimovic, V. (2001). Capital Structures in Developing Countries. The Journal of Finance, 56(1), 87-130. http://dx.doi.org/10.1111/0022-1082.00320

Caballero, S.; Teruel, P. \& Solano, P. (2010). Working Capital Management in SMEs. Accounting \& Finance, 50(3), 511-527. http://dx.doi.org/10.1111/j.1467-629X.2009.00331.x

Chittenden, F., Hall, G., \& Hutchinson, P. (1996). Small Firm Growth, Access to Capital Markets and Financial Structure: Review of Issues and an Empirical Investigation. Small Business Economics, 8, 59-67.

Chow, C. K.-W., \& Fung, M. K. Y. (2000). Small Businesses and Liquidity Constraints in Financing Business Investment: Evidence from Shangai's Manufacturing Sector. Journal of Business Venturing, 15, 363-383. http://dx.doi.org/10.1016/S0883-9026(98)00014-7

Clark, D., Berkeley, N., \& Steuer, N. (2001). Research Note: Attitudes to Growth Among Owners of Small and Medium-Sized Enterprises and the Implications for Business Advice: Some Evidence from the Clothing Industry in Coventry. International Small Business Journal, 19(3), 72-77. http://dx.doi.org/ 10.1177/0266242601193005

Clarke, F. L., Dean, G. W., \& Oliver, K. G. (1998). Corporate Collapse: Regulatory, Accounting and Ethical Failure. The Accounting Review, 73(2), 296-297. http://www.jstor.org/stable/248471

Daskalakis, Nikolaos, \& Psillaki, Maria. (2009). Do Country or Firm Factors Explain Capital Structure? Evidence from SMEs in France and Greece. Applied Financial Economics, 18(2), 87-97. http://dx.doi.org/10.1080/09603100601018864

David, J. S., Hwang, Y., Pei, B. K. W., \& Reneau, J. H. (2002). The Performance Effects of Congruence between Product Competitive Strategies and Purchasing Management Design. Management Science, 48(7), 866-885. http://dx.doi.org/10.1287/mnsc.48.7.866.2819

Desai, P., Kekre, S., Radhakrishnan, S., \& Srinivasan, K. (2001). Product Differentiation and Commonality in Design: Balancing Revenue and Cost Drivers. Management Science, 47(1), 37-51. http://dx.doi.org/ $10.1287 / \mathrm{mnsc} .47 .1 .37 .10672$

Dess, G., \& Davis, P. (1984). Porter's (1980). Generic Strategies as Determinants of Strategic Group Membership and Organizational Performance. Academy of Management Journal, 27(3), 467-488. http://www.jstor.org/stable/256040

Duryee, D. A. (1994). The Business Owner's Guide to Achieving Financial Success. Illinois, New York: Irwin.

Field, A. (2000). Discovering Statistics using SPSS for Windows. Sage. 
Foreman-Peck, J., Makepeace, G., \& Morgan, B. (2006). Growth and Profitability of Small and Medium-Sized Enterprises: Some Welsh Evidence. Regional Studies, 40(4), 307-319. http://dx.doi.org/ 10.1080/00343400600725160

Gopinath, C. (1995). Bank Strategies Toward Firms in Decline. Journal of Business Venturing, 10, 75-92. http://dx.doi.org/10.1016/0883-9026(94)00008

Hall, G., Hutchinson, P., \& Michaelas, N. (2000). Industry Effects on the Determinants of Unquoted SMEs' Capital Structure. International Journal of the Economics of Business, 7(3), 297-312.

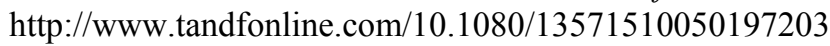

Hawawini, G., Subramanian, V., \& Verdin, P. (2003). Is Performance Driven by Industry- or Firm-Specific Factors? A New Look at the Evidence. Strategic Management Journal, 24, 1-16. http://dx.doi.org/ 10.1590/S0034-75902006002200004

Hoopes, D. G., Madsen, T. L., \& Walker, G. (2003). Guest Editors' Introduction to the Special Issue: Why is there a Resource-Based View? Toward a Theory of Competitive Heterogeneity. Strategic Management Journal, 24, 889-902. http://dx.doi.org/10.1002/smj.356

Horn, R. L. V., \& Harvey, M. G. (1998). The Rural Entrepreneurial Venture: Creating the Virtual Megafirm. Journal of Business Venturing, 13, 257-274. http://dx.doi.org/10.1016/S0883-9026(97)00012-8

Hoskisson, R. E., Hitt, M. A., Wan, W. P., \& Yiu, D. (1999). Theory and Research in Strategic Management: Swings of a Pendulum. Journal of Management, 25(3), 417-456. http://dx.doi.org/ 10.1016/S0149-2063(99)00008-2

Jensen, M. C., \& Meckling, W. H. (1976). Theory of the Firm: Managerial Behaviour, Agency Costs and Ownership Structure. Journal of Financial Economics, 3(4), 305-360. http://dx.doi.org/ 10.2139/ssrn.94043

Johnson, P., Conway, C., \& Kattuman, P. (1999). Small Business Growth in the Short Run. Small Business Economics, 12, 103-112. http://dx.doi.org/10.1023/A:1008006516084

Jordan, J., Lowe, J., \& Taylor, P. (1998). Strategy and Financial Policy in U.K. Small Firms. Journal of Business Finance \& Accounting, 25(1\&2), 1-27. http://dx.doi.org/10.1111/1468-5957.00176

Jöreskog, K. G., \& Sörbom, D. (1993). LISREL 8: Structural Equation Modelling with the SIMPLIS Command Language (5th ed.): Scientific Software International, Inc.

Kelloway, E. K. (1995). Structural Equation Modelling in Perspective. Journal of Organizational Behavior, 16(3), 215-224. http://dx.doi.org/10.1002/job.4030160304

Klapper, L.F., Sarria-Allende, V. \& Zaidi, R. (2006). A Firm-Level Analysis of Small and Medium Size Enterprise Financing in Poland (August). World Bank Policy Research Working Paper No. 3984.

Kotey, B. (1999). Debt Financing and Factors Internal to the Business. International Small Business Journal, 17(3), 11-29. http://dx.doi.org/ 10.1177/0266242699173001

Lockett, A., \& Thompson, S. (2001). The Resource-Based View and Economics. Journal of Management, 27, 723-754. http://dx.doi.org/ 10.1177/014920630102700608

Lockett, A., \& Thompson, S. (2004). Edith Penrose's Contribution to the Resource-Based View: an Alternative Perspective. Journal of Management Studies, 41(1), 193-203. http://dx.doi.org/10.1111 /j.1467-6486.2004.00428.x

Makhija, M. (2003). Comparing the Resource-Based and Market-Based Views of the Firm: Empirical Evidence from Czech Privatization. Strategic Management Journal, 24, 433-451. http://dx.doi.org/ 10.1002/smj.304

McGahan, A. M., \& Porter, M. E. (2002). What do we Know about Variance in Accounting Profitability? Management Science, 48(7), 834-851. http://www.jstor.org/stable/822694

Michaelas, N., Chittenden, F., \& Poutziouris, P. (1999). Financial Policy and Capital Structure Choice in U.K. SMEs: Empirical Evidence from Company Panel Data. Small Business Economics, 12, 113-130. http://dx.doi.org/10.1023/A:1008010724051

Mira, F. (2003). How SME Uniqueness Affects Capital Structure: Evidence From a 1994-1998 Spanish Data Panel (February). Available at SSRN: http://ssrn.com/abstract=393162 or http://dx.doi.org/10.2139/ssrn.393162

Modigliani, F., \& Miller, M. H. (1958). The Cost of Capital, Corporation Finance and the Theory of Investment. The American Economic Review, 48(3), 261-297. http://www.jstor.org/stable/i331399

Modigliani, F., \& Miller, M. H. (1963). Corporate Income Taxes and the Cost of Capital: a Correction. The American Economic Review, 53(3), 433-443. http://www.jstor.org/stable/1809167

Myers, S. C. (1977). Determinants of Corporate Borrowing. Journal of Financial Economics, 5, 147-175. http://dx.doi.org/10.1016/0304-405X(77)90015-0 
Myers, S. C. (1984). The Capital Structure Puzzle. The Journal of Finance, 39(3), 575-592. http://dx.doi.org/10.1111/j.1745-6622.1999.tb00655.x

Myers, S. C., \& Majluf, N. S. (1984). Corporate Financing and Investment Decisions when Firms have Information that Investors do not have. Journal of Financial Economics, 13, 187-221. http://dx.doi.org/10.1016/0304-405X(84)90023-0

Pelham, A. M. (1997). Mediating Influences on the Relationship Between Market Orientation and Profitability in Small Industrial Firms. Journal of Marketing Theory and Practice, 5(3), 55-76. http://www.jstor.org/stable/40469836

Pelham, A. M. (2000). Market Orientation and Other Potential Influences on Performance in Small and Medium-Sized Manufacturing Firms. Journal of Small Business Management, 38(1), 48-67. http://search.proquest.com/docview/220999047?accountid=34461

Penrose, E. (1959). The Theory of the Growth of the Firm (3rd ed.). Great Britain: Oxford University Press.

Porter, M. E. (1980). Competitive Strategy: Techniques for Analyzing Industries and Competitors. New York: Free Press.

Porter, M. E. (1985). Competitive Advantage: Creating and Sustaining Superior Performance. New York: Free Press.

Ross, S. A. (1977). The Determination of Financial Structure: the Incentive-Signalling Approach. Bell Journal of Economics, 8(1), 23-40. http://www.jstor.org/stable/3003485

Rugman, A. M., \& Verbeke, A. (2004). A Final Word on Edith Penrose. Journal of Management Studies, 41(1), 205-217. http://dx.doi.org/10.1111/j.1467-6486.2004.00429.x

Shook, C. L., David J. Ketchen Jr., Hult, G. T. M., \& Kacmar, K. M. (2004). Research Notes and Commentaries- An Assessment of the Use of Structural Equation Modelling in Strategic Management Research. Strategic Management Journal, 25, 397-404. http://dx.doi.org/10.1002/smj.385

Solano, P., \& Teruel, P. (2007). Effects of Working Capital Management on SME Profitability. International Journal of Managerial Finance, Vol. 3, No. 2, pp. 164-177. http://dx.doi.org/10.1108/ 17439130710738718

Spanos, Y. E., \& Lioukas, S. (2001). An Examination into the Causal Logic of Rent Generation: Contrasting Porter's Competitive Strategy Framework and the Resource-Based Perspective. Strategic Management Journal, 22, 907-934. http://dx.doi.org/10.1002/smj.174

Spanos, Y. E., Zaralis, G., \& Lioukas, S. (2004). Strategy and Industry Effects on Profitability: Evidence from Greece. Strategic Management Journal, 25, 139-165. http://dx.doi.org/10.1002/smj.369

Stiglitz, J. E., \& Weiss, A. (1981). Credit Rationing in Markets with Imperfect Information. The American Economic Review, 73(June), 393-409. http://www.jstor.org/stable/1802787

Storey, D. J. (1994). Understanding the Small Business Sector. London: Routledge.

Sulek, J. M., Lind, M. R., \& Marucheck, A. S. (1995). The Impact of a Customer Service Intervention and Facility Design on Firm Performance. Management Science, 41(11), 1763-1773. http://www.jstor.org /stable/2632872

Tabachnik, B. G., \& Fidell, L. S. (2001). Using Multivariate Statistics (4th ed.): Allyn and Bacon.

Tacq, J. (1997). Multivariate Analysis Techniques in Social Science Research-From Problem to Analysis: Sage.

Teruel, P., \& Solano, P. (2008). On the Determinants of SME Cash Holdings: Evidence from Spain. Journal of Business Finance \& Accounting, Vol. 35, Issue 1-2, pp. 127-149. http://dx.doi.org/10.1111/j.1468-5957.2007.02022.x

Teruel, P., \& Solano, P. (2010). A Dynamic Approach to Accounts Receivable: A Study of Spanish SMEs. European Financial Management, Vol. 16, No. 3, pp. 400-421. http://dx.doi.org/10.1111/j.1468-036X.2008.00461.x

Titman, S., \& Wessels, R. (1988). The Determinants of Capital Structure Choice. The Journal of Finance, 43(1), 1-19. http://www.jstor.org/stable/2328319

Toit, M. d., \& Toit, S. d. (2001). Interactive Lisrel: User's Guide. Scientific Software International, Inc.

Toy, N., Stonehill, A., Remmers, L., Wright, R., \& Beekhuisen, T. (1974). A Comparative International Study of Growth, Profitability, and Risk as Determinants of Corporate Debt Ratios in the Manufacturing Sector. Journal of Financial and Quantitative Analysis, 9, 875-886. http://dx.doi.org/ 10.2307/2329684

Ullman, J. B. (2001). Structural Equation Modelling. In Using Multivariate Statistics (4th ed.): Allyn and Bacon.

Van Caneghem, Tom and Van Campenhout, Geert, Information Availability, Information Quality and the Financial Structure of Belgian SMEs (October 1, 2009). Small Business Economics; Finance and Corporate Governance Conference 2010; HUB RESEARCH PAPER 2009/27. Available at SSRN: http://ssrn.com/abstract=1541793

Wonnacott, T. H., \& Wonnacott, R. J. (1990). Introductory Statistics (5th ed.): John Wiley \& Sons. 
Table 1. Measurement equations

\begin{tabular}{|c|c|c|}
\hline$=0.94$ nodebt & Error var. $=0.12$ & $\mathrm{R}^{2}=0.88$ \\
\hline AVDER1 $=-0.82$ nodebt & Error var. $=0.33$ & $\mathrm{R}^{2}=0.67$ \\
\hline$=-0.39$ differen -0.34 lackliq & Error var. $=0.87$ & $\mathrm{R}^{2}=0.13$ \\
\hline$=-0.59$ lackliq & Error var. $=0.65$ & $\mathrm{R}^{2}=0.35$ \\
\hline LIQCRISI $=0.83$ lackliq & Error var. $=0.31$ & $\mathrm{R}^{2}=0.69$ \\
\hline SUPHONE $=0.51$ lackliq & Error var. $=0.74$ & $\mathrm{R}^{2}=0.26$ \\
\hline SUPDISC $=-0.67$ lackliq & Error var. $=0.55$ & $\mathrm{R}^{2}=0.45$ \\
\hline$=1.00$ educatio & & $\mathrm{R}^{2}=1.00$ \\
\hline$=1.00$ roapot & & $\mathrm{R}^{2}=1.00$ \\
\hline$=1.00$ growpot & & $\mathrm{R}^{2}=1.00$ \\
\hline BUDGET $=0.35$ differen +0.69 lowcost & Error var. $=0.45$ & $\mathrm{R}^{2}=0.55$ \\
\hline LOWCOST $=0.20$ lowcost & Error var. $=0.96$ & $\mathrm{R}^{2}=0.040$ \\
\hline OWNSTOR $=-0.76$ lowcost & Error var. $=0.43$ & $\mathrm{R}^{2}=0.57$ \\
\hline MPLIST $=0.38$ lowcost & Error var. $=0.85$ & $\mathrm{R}^{2}=0.15$ \\
\hline TRUEACC $=0.70$ lowcost & Error var. $=0.51$ & $\mathrm{R}^{2}=0.49$ \\
\hline OWNPROD $=0.57$ differen & Error var. $=0.67$ & $\mathrm{R}^{2}=0.33$ \\
\hline$=0.58$ differen & Error var. $=0.66$ & $\mathrm{R}^{2}=0.34$ \\
\hline$=0.52$ differen & Error var. $=0.73$ & $\mathrm{R}^{2}=0.27$ \\
\hline PRODELAY $=-0.47$ differen & Error var. $=0.78$ & $\mathrm{R}^{2}=0.22$ \\
\hline$=1.00$ prodfocu & & $\mathrm{R}^{2}=1.00$ \\
\hline$=1.00$ cusfocus & & $\mathrm{R}^{2}=1.00$ \\
\hline
\end{tabular}

Table 2. Composition of variables

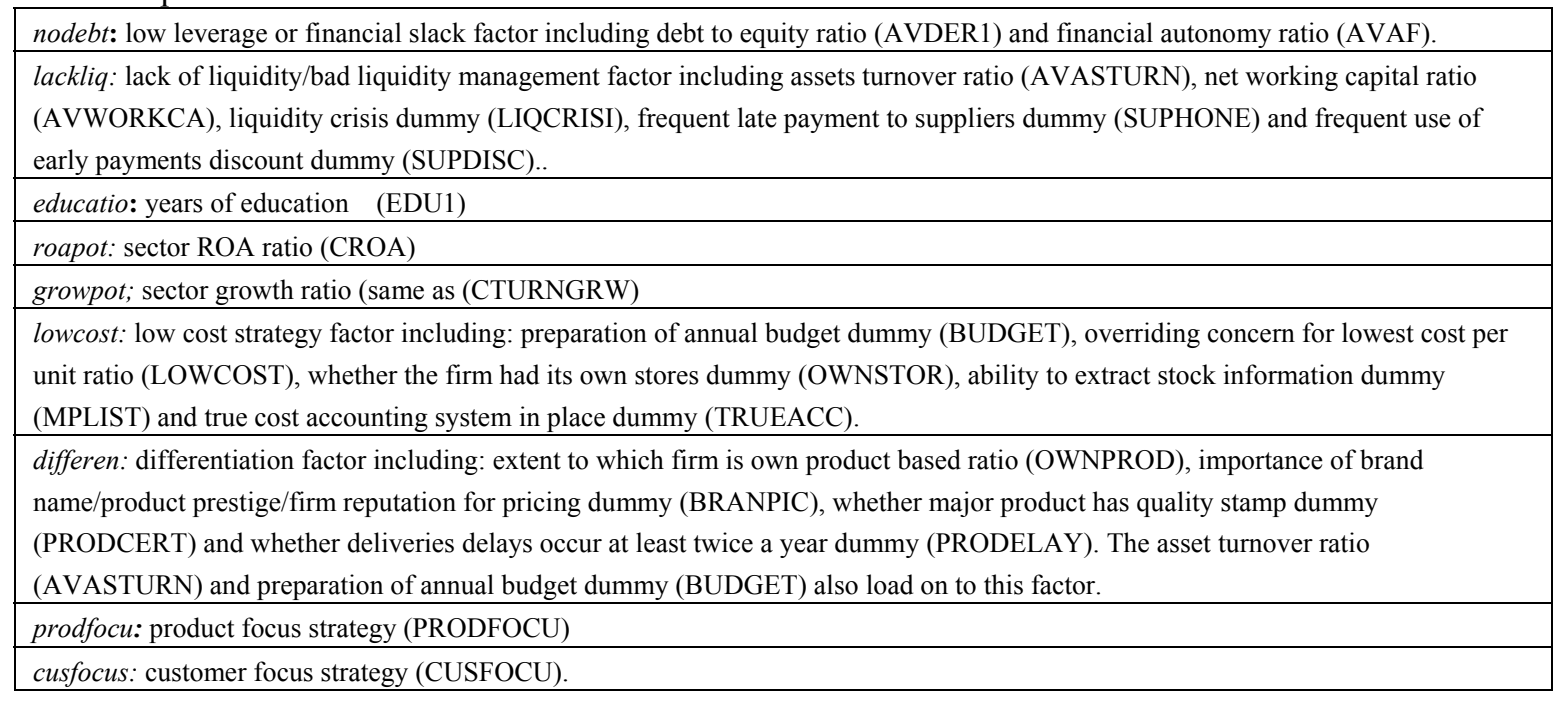


Table 3. Structural Equations (before rotation for highly correlated factors)

\begin{tabular}{|ll|}
\hline ROA $=$ & \\
\hline-0.79 nodebt $(0.15)$ & $\mathrm{t}=-5.22^{*}$ \\
\hline-1.34 lackliq $(0.14)$ & $\mathrm{t}=-9.30^{*}$ \\
\hline+0.12 educatio $(0.16)$ & $\mathrm{t}=0.77$ \\
\hline+0.43 roapot $(0.095)$ & $\mathrm{t}=4.55^{*}$ \\
\hline-0.027 lowcost $(0.18)$ & $\mathrm{t}=-0.16$ \\
\hline-0.47 differen $(0.13)$ & $\mathrm{t}=-3.70^{*}$ \\
\hline-0.064 prodfocu $(0.045)$ & $\mathrm{t}=-1.42$ \\
\hline-0.084 cusfocus $(0.049)$ & $\mathrm{t}=-1.73^{*}$ \\
\hline Errorvar.=0.38 $(0.11)$ & $\mathrm{t}=3.57^{*}$ \\
\hline $\mathrm{R}^{2}=0.62$ & \\
\hline
\end{tabular}

\begin{tabular}{|ll|}
\hline GROWTH $=$ \\
\hline-0.50 nodebt $(0.19)$ & $\mathrm{t}=-2.56^{*}$ \\
\hline-0.38 lackliq $(0.15)$ & $\mathrm{t}=-2.63^{*}$ \\
\hline+0.19 educatio $(0.18)$ & $\mathrm{t}=1.06$ \\
\hline+0.016 growpot $(0.050)$ & $\mathrm{t}=0.32$ \\
\hline+0.047 lowcost $(0.091)$ & $\mathrm{t}=0.52$ \\
\hline+0.089 differen $(0.058)$ & $\mathrm{t}=1.55$ \\
\hline+0.15 prodfocu $(0.033)$ & $\mathrm{t}=4.66^{*}$ \\
\hline+0.059 cusfocus $(0.038)$ & $\mathrm{t}=1.55$ \\
\hline Errorvar.=0.81 $(0.100)$ & $\mathrm{t}=8.16^{*}$ \\
\hline $\mathrm{R}^{2}=0.19$ & \\
\hline
\end{tabular}

* significant at the $5 \%$ level

Table 4. t-statistics for structural equations after rotation

\begin{tabular}{|c|c|c|}
\hline Factor & ROA & Growth \\
\hline nodebt & $+5.51^{*}$ & -0.64 \\
\hline lackliq & $-7.77^{*}$ & $-1.99^{*}$ \\
\hline eductio & +0.77 & +1.06 \\
\hline roapot & $+4.55^{*}$ & -- \\
\hline growpot & -- & +0.32 \\
\hline lowcost & $-3.67^{*}$ & -1.31 \\
\hline different & $+2.80^{*}$ & $+5.59^{*}$ \\
\hline prodfocu & -1.42 & $+4.66^{*}$ \\
\hline cusfocus & $-1.73^{*}$ & +1.55 \\
\hline
\end{tabular}

\section{Appendix 1. Database 1 (A1B1C1): Parameter Estimates}

A1: No transformations performed; B1: Retention of univariate outliers with alteration; C1: Imputation of missing values on SECTOR TURNOVER GROWTH 


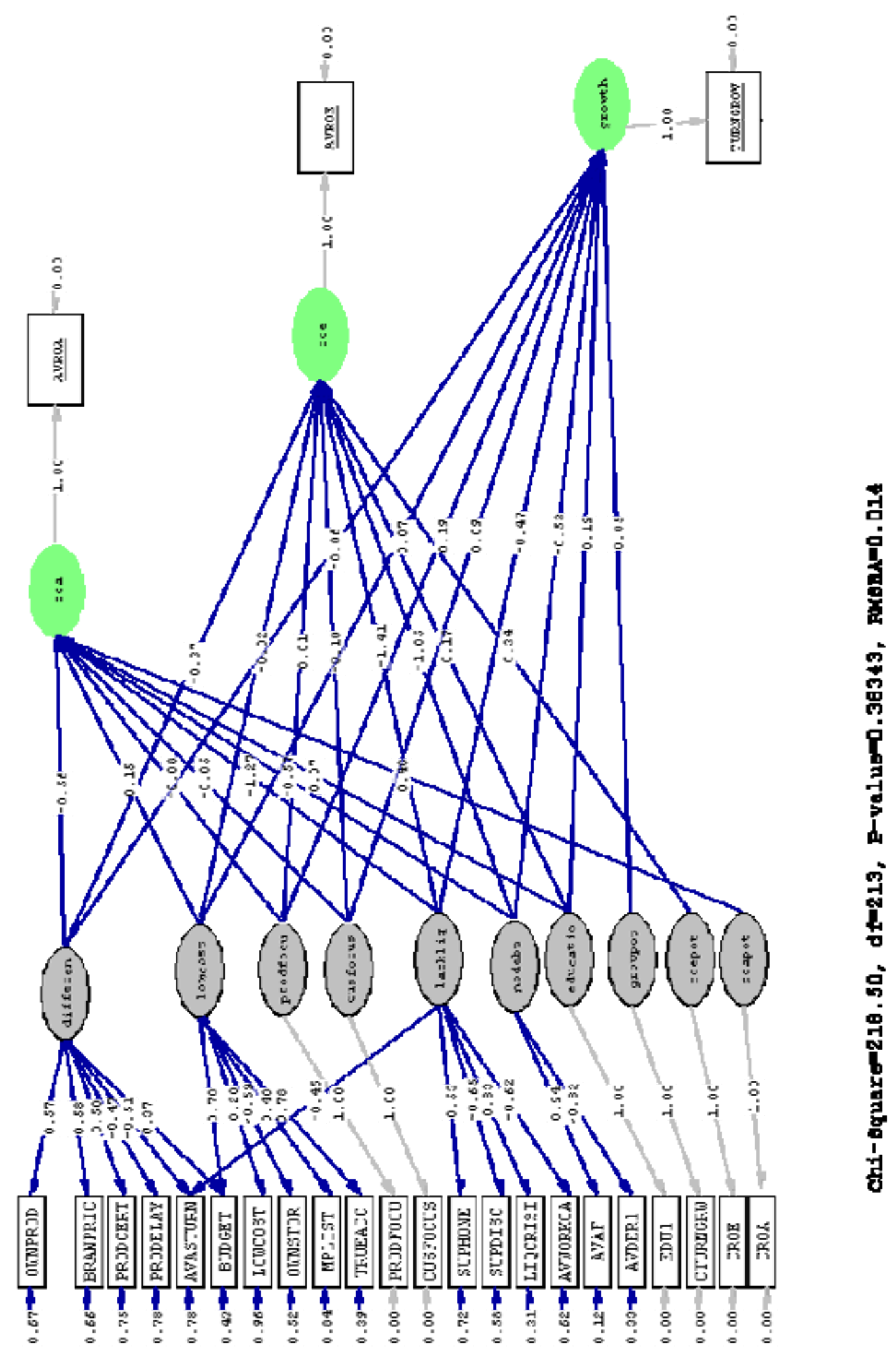

Appendix 1 (cont). Database 1 (A1B1C1): LISREL Model T-Values

A1: No transformations performed; B1: Retention of univariate outliers with alteration; $\mathrm{C} 1$ : Imputation of missing values on SECTOR TURNOVER GROWTH 


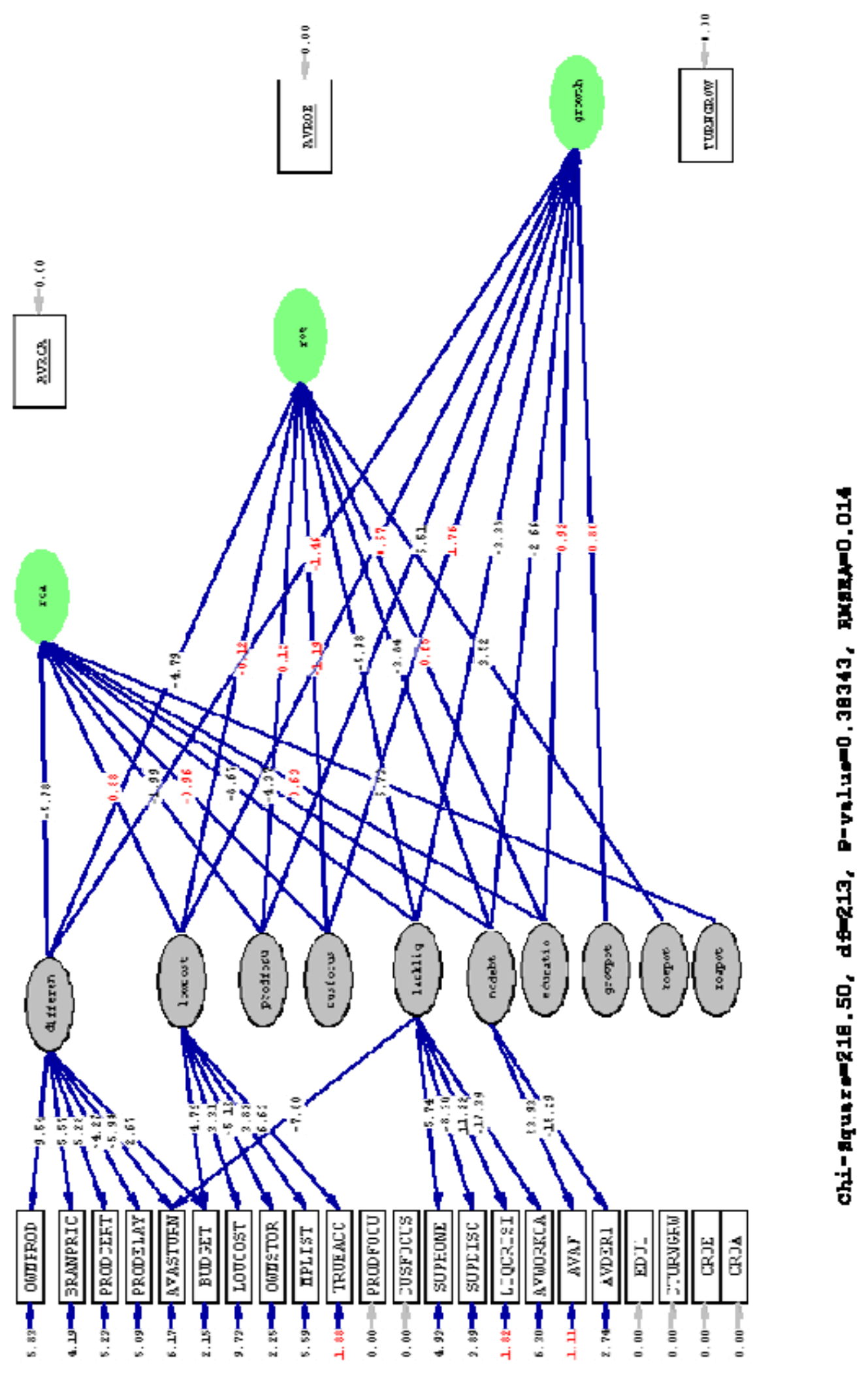




\section{Appendix 1 (cont). Database 1 (A1B1C1): LISREL Model in Equation Form}

A1: No transformations performed; B1: Retention of univariate outliers with alteration; $\mathrm{C} 1$ : Imputation of missing values on SECTOR TURNOVER GROWTH

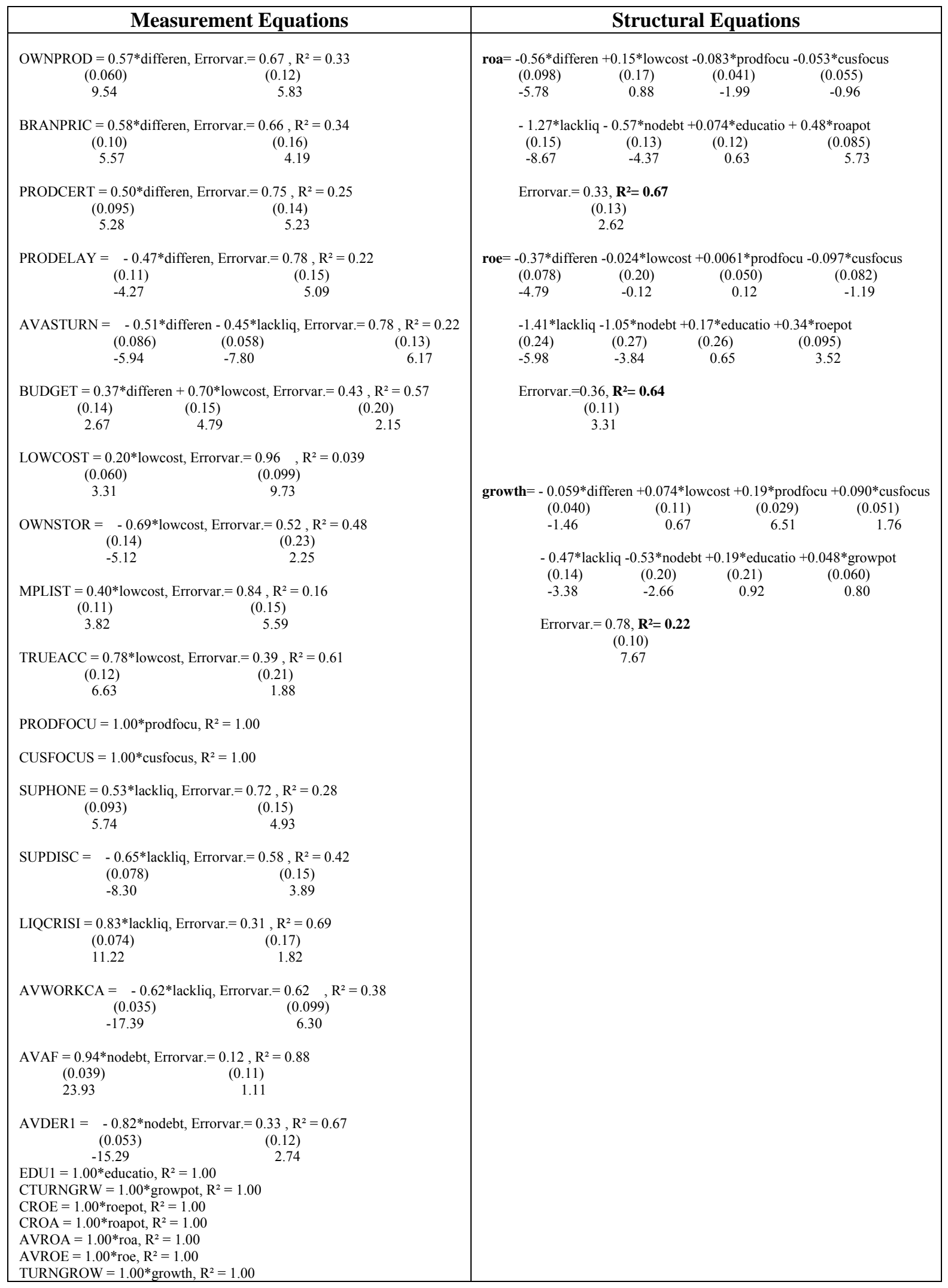




\section{Legend for Appendix 1}

OWNPROD: extent to which the firm is own-product based.

BRANPRIC: whether brand name, product prestige, or firm reputation is important for the firm's pricing.

PRODCERT: whether major product has a quality stamp on it.

PRODELAY: whether deliveries delays occur at least twice a year.

AVASTURN: assets turnover ratio.

BUDGET: whether the firm prepares budgets at least on a yearly basis.

LOWCOST: importance attached to continuing, overriding concern for the lowest cost per unit.

OWNSTOR: whether the firm has its own stores.

MPLIST: whether the firm is able to extract a reliable and computerised list of stocks of raw materials at any time.

TRUEACC: whether the firm has a true cost accounting system in place.

PRODFOCU: percentage of total turnover contributed by major product.

CUSFOCUS: percentage of total turnover contributed by the most important customer type.

SUPHONE: whether the firm frequently pays suppliers late.

SUPDISC: whether the firm frequently uses early payment discounts.

LIQCRISI: whether the firm has experienced a severe liquidity crisis over the past 5 years.

AVWORKCA: net working capital ratio.

AVAF: financial autonomy ratio.

AVDER1: debt to equity ratio.

EDU1: years of education of the most influential manager in the firm.

CROA: sector ROA.

CROE: sector ROE.

CTURNGRW: sector turnover growth.

differen: differentiation strategy.

lowcost: low cost strategy.

prodfocu: product focus strategy.

cusfocus: customer focus strategy.

lackliq: lack of liquidity/bad liquidity management.

nodebt: low leverage or financial slack.

educatio: years of education of the most influential manager in the firm.

roapot: sector ROA.

roepot: sector $R O E$.

growpot: sector turnover growth.

AVROA: firm ROA.

AVROE: firm ROE.

TURNGROW: firm turnover growth. 